\title{
インクジェット記録用紙の最近の技術動向
}

十條製紙(侏中央研究所小島裕

\section{Inkjet Paper}

\author{
Yutaka Kojima \\ Jujo Paper Co., Ltd. Central research Laboratory
}

Inkjet printing system already has the history of more than two decades. But the market has been yet small because of the lack of its reliability and popularity.

Recetry, however, it is attracting increasing interest from color printing system developers as one of prospective non-inpact systems.

In this article, several important qualities of inkjet papers are briefly discussed. They are good ink absorbency, appropriate dot diameter, dot circularity, high optical density, good color reproduction, good resistance to severe enviromental conditions, and good paper feeding qualities.

In recent research, these requirements have been almost solved, and the system will surely be accepted in the market.

\section{1. インクジェット記録の概要}

インクジェットは非接触印字, 低騷音, カラー記録, 簡易性などを主な特徴とする記録方式で，ノンインパ クト記録方式の代表的なものである。すでに 20 年以上 の歴史をもつつ記録方式であるが, これまで信頼性やメ ンテナンスに問題が多く国内では感熱記録や熱転写記 録ほど普及せず，ユーザーも少なく大きな市場も確保 することができなかった。一方，図 1 1,2) は現時点での ノンインパクト記録方式の性能比較である。インク ジェット技術は解像度, カラー記録, コストの点で特 に優れたものであることを示されている。そして国内 では最近, PPCのフルカラーコピー, カラー静電記 録, 溶融型や昇華型の熱転写記録, MEAD 社が開発し たカプセルを利用した圧力現像方式のサイカラーなど を中心とするカラー記録技術が一段と進み，カラー記 録に対する認識にも変化がみえはじめ, インクジェッ 卜記録方式の優位性も改めて見直されつつあり，更に 信頼性やメンテナンスの問題も克服されプリンタの出 荷台数も徐々に増えつつあるのが現状である。

インクジェット技術は，インク液体に熱あるいは圧 力を加える, または励振させることなどにより, 直径 数十ミクロン程度の小さいノズルからインクを押しだ しインク粒子を形成し飛翔させて, 被記録物上に文字
や画像を得るものである。このインクジェット記録技 術の特徴を改めてまとめてみると以下のようになる。

(1) カラ一記録が容易である

(2) 非接触印字であり騒音が少ない

(3) 高精細な画像が得られる

(4) 高速印字が可能
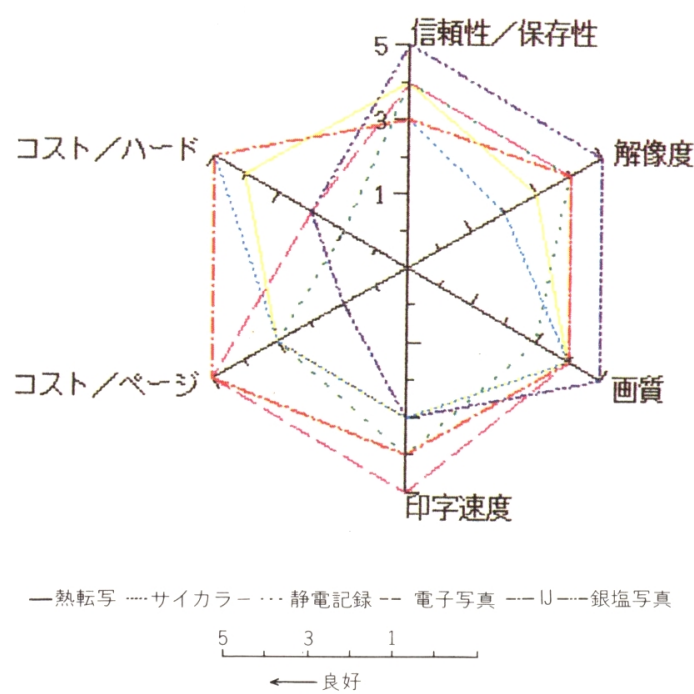

図 1 ノンインパクト記録方式の性能比較 
(5) 低ランニングコストである

(6) 被記録物の形状にとらわれない

(7) 普通紙でも印字可能

欠点としては,

(1) 環境条件に弱い, 温湿度変化によるインク組成 の変化やインクの凝集等

(2) 塵や埃, 紙粉，エアーなどによるノズル詰まり

(3)運搬時などの振動に弱い

これらの欠点も様々な形で克服されつつある。

インクジェット技術をインク粒子化法で分類してみ ると表 1 に示すようなオンディマンド型と荷電制御型 に大別されるが，図 2 にはそれぞれ代表的なインクノ ズルのインク粒子吐出の模式図を示した。オンディマ ンド型は圧力パルス方式 (図 2 a) ${ }^{3)}$ やサーマルジェッ 卜方式 (図 2 b) ${ }^{3)}$ に代表されるよjに，必要なときの みにインクを吐出するものであり，小型化，ノズルの 高集積化, 低価格化などの利点があり各種のプリンタ に用いられている。一方, 荷電制御型 (図 2 c $)^{4)}$ はイ ンク粒子を連続的に噴射し必要な粒子を荷電量によっ て制御し被記録物に打ち込み，不必要な粒子は回収す る，または除去する方法をとっている。高速化，高精 細の利点があるが励振, 高電圧, インク回収装置など が必要で装置が大型になっている。最近の特有な粒子 化方法としてはスパークジェット (固形インク), 熱溶 融インクジェット, 空電制御型インクジェット（油性
インク）等がみられる。

IJ 記録の最も重要な技術要素の一つはインクであ り，その優れたカラー記録, 安定性, 信頼性はインク の特性によって決定される。それ故インクに求められ る要求物性は多岐にわたるだけでなくそれぞれの要求 レベルが高い。また粒子化の方法によって使用される インクの種類や物性, インク粒子径, 単位面積当りに 吐出されるインクの量などが異なっている。

インクについて簡単に要求特性 ${ }^{5,6)}$ を並べてみると, (1)インクの安定吐出領域や動作温度範囲が広いなどの 動作特性, (2)インとして記録濃度, 色相, 速やかな 浸透乾燥, 耐水性, 耐光性などの記録特性, (3)目詰ま りや保存安定性などの信頼性や安全性の点等が問題と される。IJ インクの組成と物性はおおよそ表 2 に示す ようなものである。組成は一般に着色剂として水溶性 の酸性染料や直接染料, 溶媒として水やアルコール, ポリエチレングライコール等の湿潤剤などで構成され る。インクは粒子化方式の違いによりその組成や物性 がそれぞれ異なる。オンディマンド型では溶媒として 水のほかインク乾燥によるノズル詰まりを防ぐため, 湿潤剤エチレングライコール等の溶媒の添加量が多い ため粘度がやや高い傾向にあり，またジエ夕ノールア ミン等の高沸点の吸湿剤などが含まれる。連続噴射型 では溶媒として水の比率が高い, あるいはアルコール 類が添加される等の理由からインクの粘度は低い。更

表 1 インク粒子化方式の分類とインク・用紙

\begin{tabular}{|c|c|c|c|c|}
\hline \multicolumn{2}{|r|}{ インク粒子化方式 } & インク & \multirow{2}{*}{$\begin{array}{l}\text { 用 紙 } \\
\text { 専用紙 }\end{array}$} & \multirow{2}{*}{$\begin{array}{l}\text { メ } \\
\\
\text { 日立製作所, IBM, NTT } \\
\text { 沖電気, A.B. ディック } \\
\text { APPLICON, ミノルタ }\end{array}$} \\
\hline $\begin{array}{l}\text { 連 } \\
\text { 続 } \\
\text { 㨁 } \\
\text { 型 }\end{array}$ & $\begin{array}{l}\text { 荷電制御型 } \\
\text { (1) Sweet 型 } \\
\text { (2) Hertz 型 }\end{array}$ & $\begin{array}{l}\text { 水 性 } \\
\text { 水 性 }\end{array}$ & & \\
\hline & 空電制御型 & 油 性 & （普通紙） & 松下技研 \\
\hline $\begin{array}{l}\text { オ } \\
\text { ン } \\
\text { デ } \\
1 \\
マ \\
\text { マ }\end{array}$ & $\begin{array}{l}\text { 圧カパルス } \\
\text { (1) Stemme 型 } \\
\text { (2) Kyser 型 } \\
\text { (3) Gould 型 }\end{array}$ & $\begin{array}{l}\text { 水 性 } \\
\text { 水 性 } \\
\text { 水 性 }\end{array}$ & $\begin{array}{l}\text { 専用紙 } \\
\text { 普通紙 } \\
\text { 専用紙 } \\
\text { (普通紙) } \\
\text { 専用紙 }\end{array}$ & $\begin{array}{l}\text { 松下電子部品, 三洋, 富士フイルム } \\
\text { シャープ } \\
\text { コニカ } \\
\text { セイコーエプソン } \\
\text { シーメンス, 日本電気 }\end{array}$ \\
\hline $\begin{array}{l}\text { ド } \\
\text { 型 }\end{array}$ & $\begin{array}{l}\text { サーマルジェット } \\
\text { (バブルジェット) } \\
\text { 磁性インクジェット } \\
\text { 熱溶融インクジェット }\end{array}$ & $\begin{array}{ll}\text { 水 } & \text { 性 } \\
& \\
\text { 磁 } & \text { 性 } \\
\text { 固 } & \text { 体 }\end{array}$ & $\begin{array}{l}\text { 専用紙 } \\
\text { 普通紙 } \\
\text { 普通紙 } \\
\text { 普通紙 }\end{array}$ & $\begin{array}{l}\text { HP } \\
\text { キャノン } \\
\text { 松下電産 } \\
\text { Howtek }\end{array}$ \\
\hline
\end{tabular}

注）専用紙……インクジェット用に開発された特殊紙

普通紙……市販上質紙 


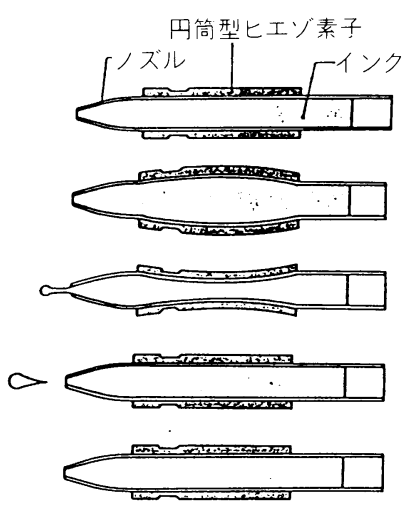

図 $2 \mathbf{a}$

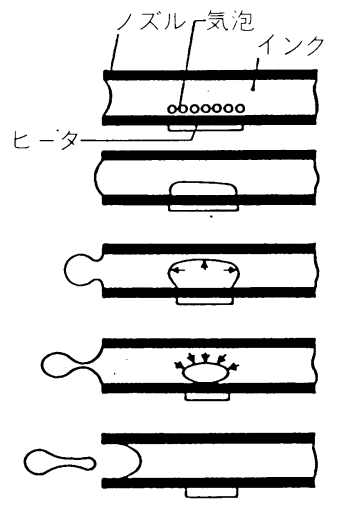

図 $2 b$

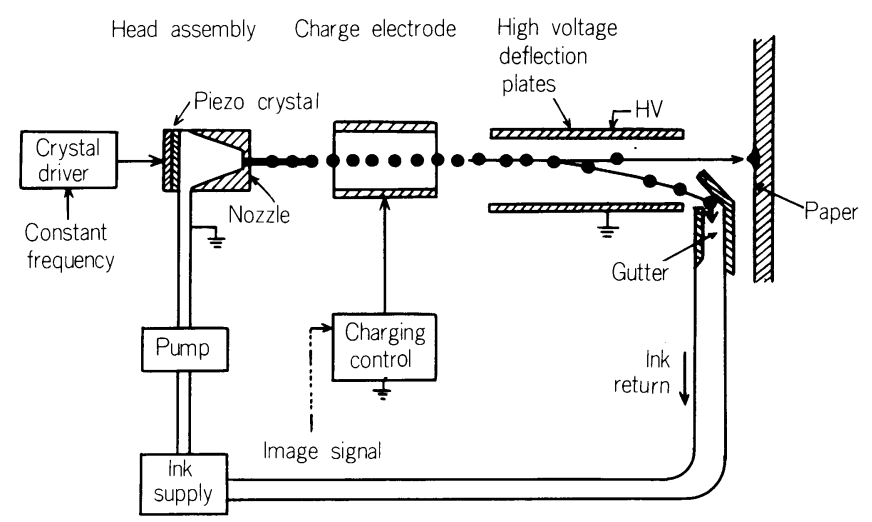

図 2 c

図 2 代表的なインク粒子化方式

に荷電調整の目的で電解質等を加えるケースもあるな ど，それぞれ粒子化方法にあわせて特徵がある。

インクはこれら機器に対応するだけでなく, 最近で はIJ 技術の普及の試みとして普通紙対応のインクの 開発も進み実用化されている。例えば普通紙に印字可 能なインクとしては, pH 13 程度に調製したアルカリ 性インクブがあり, 紙に用いられているロジン系サイ ズ剤の成分がアルカリ条件下で签化反応を起こして溶 解することを利用したものである。このほか界面活性 剤などインク浸透剤を添加して普通紙印字を可能にし たもの数多くみられる。しかしこれらのインクはアル キルケテンダイマーやアルケニル無水コハク酸などの 反応性のサイズ剤に対しては効果は少ないものがある。 インク粒子化技術発展の中で, 上述したようにIJ イ ンクはそれぞれ特有のノズルの粒子化条件, 動作特性, 安定性などを中心に，また普通紙及び尃用記録紙に対 応すべく開発されてきた。そして記録紙はこれら粒子 化方式，あるいはインク特性に対応して設計されてき
表 2 インクジェットインクの組成と物性

\begin{tabular}{|c|c|c|}
\hline \multirow{3}{*}{ 組 } & 着色材 & 染料，まれに顔料 \\
\hline & 溶媒 & 水, アルコール類 \\
\hline & 湿潤剤 & $\begin{array}{l}\text { グリコール類, グリコールエーテル類 } \\
\text { アミド類, ピロリドン類その他 }\end{array}$ \\
\hline 成 & 添加剤 & $\begin{array}{l}\text { 結着剂, 界面活性剂 } \\
\text { 酸素吸収剂, 防徽剂 } \\
\text { 物性調整剮, キレート化剂 } \\
\text { 荷電調節剤 その他 }\end{array}$ \\
\hline 物 & $\begin{array}{l}\text { 粘度 } \\
\text { 表面張力 } \\
\mathrm{pH} \\
\text { 比抵抗 } \\
\text { 比熱 }\end{array}$ & $\begin{array}{l}1 \sim 30 \mathrm{c} . \mathrm{p} . \mathrm{s} \\
10 \sim 60 \mathrm{dyn} / \mathrm{cm} \\
6 \sim 13 \\
10^{-1} \sim 10^{11} \Omega \cdot \mathrm{cm} \\
0.5 \sim 10 \mathrm{~J} / \mathrm{gK}\end{array}$ \\
\hline
\end{tabular}


たのが,これまでの IJ 技術の発展の過程であった。し かし, 今後どの粒子化方法が主流となって行くかは, インクジェット記録技術の範疇としてだけではなく， 他の記録方式と比較した上で選択されて行くことにな る。IJ 記録技術が各種プリンタの画像出力機器として 沉用化されていくには, 高速性, 簡便性, 小型化, 高 解像度 (ノズルの高集積化), 高画質, メンテナンスフ リ一，低価格などの数多くの課題が克服されなければ ならない。

\section{2. インクジェット記録用紙について}

インクジェット記録を一般の印刷物として捉えた場 合, どんな点が要求されるかを並べてみる。まず第 1 に画質特性としては, カラーの場合; 色鮮明性や色再 現性に優れ, 見かけの記録濃度が高い, 十分な濃度階 調性があること等が求められる。第 2 にインク粒子を 記録紙に打ち込んだときに生ずるドットの印字特性の
問題がある。具体的にはドット濃度が高い, インクの 流れだし (running) がない, インクの適度な広がり (spread) があり，にじみ (smearing) がないこと、イ ンクの滲み込み (bleeding) がない, インクの跳ね返り (splatter) がないこと等が求められる。第 3 に記録の 保存性, 例之ば画像の耐水性, 耐光性, 室内保存性, 耐摩擦性である。第 4 に一般紙質特性として, 普通紙 である，あるいは普通紙に近いものであることが望ま れ, 記録紙の搬送性, 風合いや手触りなど, 筆記性や 捺印性など，オフセットなどの印刷適性など様々なも のが要求される。

製紙の立場からこれらの特性を満足させるようなイ ンクジェット記録用紙を作り出すことを考えてみると, 表 3 に揭げるような内容が検討されなければならない。 すなわち(1) IJ 記録としての記録特性, (2)主にインクに 含まれる染料との関係で生ずる記録保存性について, (3)用紙のハンドリングないしは搬送性の問題, (4)一般

表 3 インクジェット用紙の要求特性

\begin{tabular}{|c|c|c|}
\hline \multicolumn{2}{|c|}{ インクジェット用紙の要求特性 } & 紙として検討する項目 \\
\hline (1)記録特性 & $\begin{array}{l}\text { a ) インク吸収容量 } \\
\text { b ) インク吸収速度 } \\
\text { c) ドット径, ドット形状 } \\
\text { d) 記録濃度 } \\
\text { e ) ブリーディング } \\
\text { f) 濃度階調性 } \\
\text { g ) 画像鮮明性 }\end{array}$ & $\begin{array}{l}\text { 1) 物理的特性 } \\
\text { 空隙率, 空隙量 } \\
\text { 表面粗さ, 平滑度 } \\
\text { 空隙形状, 透気度 } \\
\text { 紙の粗さ指数 } \mathrm{K}_{\mathrm{r}} \text {, 吸収係数 } \mathrm{K}_{\mathrm{a}} \\
\text { 接触角 (動的, 静的) } \\
\text { 2) 化学的特性 } \\
\text { ぬれ, 染料親和性 } \\
\text { 3) 光学的特性 } \\
\mathrm{S} \text { 值, 不透明度 }\end{array}$ \\
\hline $\begin{array}{l}\text { (2)記録保存 } \\
\text { 性 }\end{array}$ & $\begin{array}{l}\text { a) 画像耐水性 } \\
\text { b) 画像耐光性 } \\
\text { c）画像室内外保存性 } \\
\text { d）用紙保存性（変色退色） }\end{array}$ & 各種添加剤の検討 \\
\hline $\begin{array}{l}\text { (3)般送性と } \\
\text { ハンドリ } \\
\text { ング }\end{array}$ & $\begin{array}{l}\text { a ) フィードトラブル (般送) } \\
\text { b ) 給・排紙トラブル } \\
\text { c) コックリング (吸収ジワ) } \\
\text { d ) カール, 波打ち } \\
\text { e ) 紙粉 }\end{array}$ & $\begin{array}{l}\text { 平滑度, 摩擦係数 } \\
\text { 引剛度, 曲げ強度, 紙のこし } \\
\text { 引張強度, 引裂強度 }\end{array}$ \\
\hline $\begin{array}{l}\text { (4)一般紙と } \\
\text { しての要 } \\
\text { 望点 }\end{array}$ & $\begin{array}{l}\text { a ) インクの裏抜け } \\
\text { b ) 印刷適性 } \\
\text { c）筆記性 } \\
\text { d）紙の白さ } \\
\text { f ）手触り } \\
\text { g）風合 } \\
\text { h）その他 }\end{array}$ & $\begin{array}{l}\text { 坪量, 厚さ } \\
\text { サイズ度, 表面強度 } \\
\text { 不透明度, 白色度 } \\
\text { 浸水伸度, 寸法安定性 (伸び) } \\
\text { 水分 }\end{array}$ \\
\hline
\end{tabular}


用紙としての風合いも含めた紙質特性など四つの項目 に分けることができる。

現在使用されているインクジェット記録用紙を分類 してみると図3のようなインク吸収形態に分けること
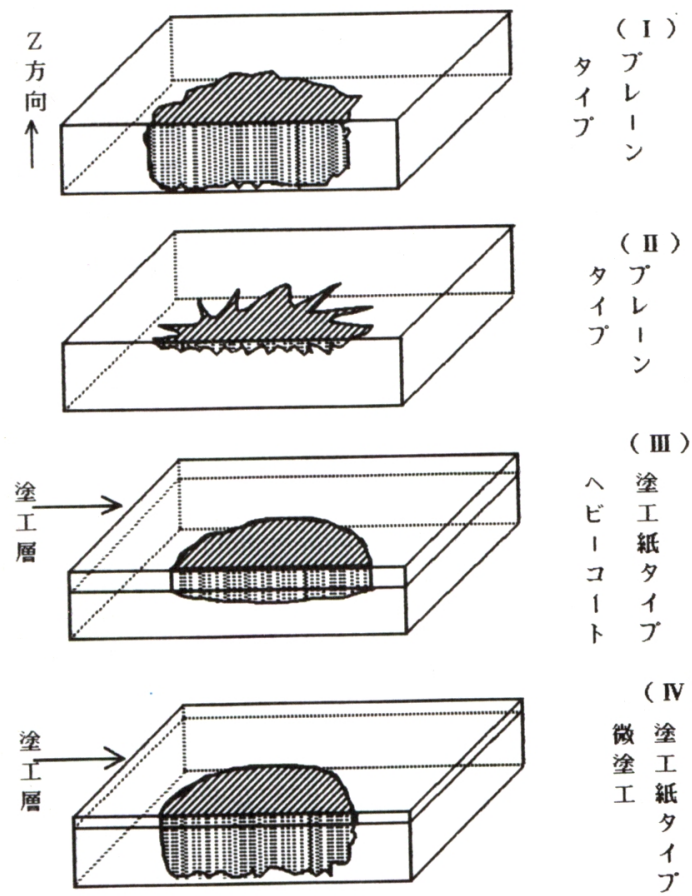

( IV )

徐

塗 I

工 紙

夕

1

図 3 インクジェット記録用紙の分類 インクの吸収状態とドットの形状
ができる。プレーン紙では表面サイズなどでコント ロールされた吸収型（I）と非吸収型（II）のタイプ のものがあり, 塗工紙としてはへビーコート（III） と 微塗工 (IV) のものに分けられる。それぞれの性能を 図 4 に示す。以下，本稿ではインクジェット記録用紙 の要求特性のなかで重要と思われるインク吸収性, ドット径とドットの真円度, 記録濃度, 記録保存性, 用紙の搬送特性の各点について述べていく。

\section{3. インク吸収性}

\section{1 インク吸収容量と吸収速度}

$\mathrm{IJ}$ 記録ではインク液として $\mathrm{m}^{2}$ 当り数 $\mathrm{m} l$ から多い もので十数 $\mathrm{m} l$ の量がインク受容層に打ち込まれる。 記録紙としてはこのインク液を一旦取り込む空隙容積 が必要となる。またその印字速度は毎秒数 $\mathrm{cm}^{2}$ から $300 \mathrm{~cm}^{2}$ にも達するものがあり, 更に実際のプリン夕 では紙押えのペーパーロールなどがありインク乾燥の 点から言えば，インクの吸収速度はかなり速いものが 求められる。記録紙のインク吸収層を毛細管の集合体 とみなすならば, 単位面積当り $\mathrm{N}$ 本の毛細管が存在 し, 毛細管の平均細孔径 $r$, 各毛細管が $\mathrm{t}$ 時間後に満た される毛細管の平均高さを $\mathrm{h}$ とすると, 単位面積当た りに吸収されるインクの堆積 $\mathrm{V}$ は,

$$
\mathrm{V}=\mathrm{N} \pi \mathrm{r}^{2} \mathrm{~h}
$$

で表わされ, 空吵率 $\varepsilon$ と屈曲係数 $\tau$ の関係は

$$
\varepsilon=\mathrm{N} \pi \mathrm{r}^{2} \tau
$$

となり, h に Lucas-Washburnの式を当てはめ, (1)(2)

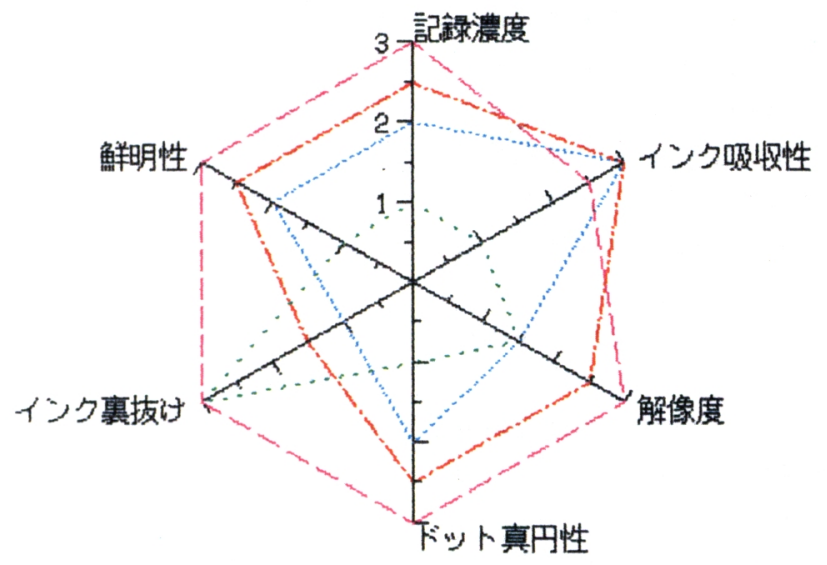

…… プレーン紙( I ) … プレーン紙( II )
.-- 微塗工紙( IV )

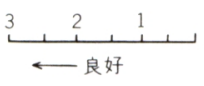

図 4 インクジェット用紙の性能比較 
式から V は(3)式で表わすことができる。

$$
\mathrm{V}=\frac{\varepsilon}{\tau}\left(\frac{\mathrm{r} \gamma \cos \theta}{2 \eta} \cdot \mathrm{t}\right)^{1 / 2}
$$

ここで, $\gamma$ : インクの表面張力, $\eta:$ インクの粘度, $\theta$ : 接触角を表わす。この式から， r， $\varepsilon$ をある程度大きく して $\theta$ 及び $\tau$ を小さくることにより，一定量のイン クを吸収する時間を短くすることが可能になる。 $\mathrm{r}, \varepsilon$, $\tau$ はインク受容層の構造に, $\gamma, \eta$ はインクの物性に, $\theta$ はインクとインク受容層面の化学的親和性に大きく 依存している。

このようなインクの吸収容量及び吸収速度を満足さ せるには，まずインクが吸収されるべきインク受容層 の細孔の空隙量が確保されなければならない。更にパ ルプ纎維と填料，あるいは䪺料とバインダーなどで構 成される細孔の形状・大きさ，細孔分布とその平均細 孔径等が適切な範囲にあることが望まれる。

\section{2 紙の表面ぬれとインクの浸透}

さらにIJインクには上述したように水以外にジエ チレングライコールや，ポリエチレングライコールな どが湿潤剤として含まれており，これら水との混合溶 媒は紙表面の状態や材料によって化学的親和性が異な るため，インク受容層の表面でのぬれや浸透に影響を 与える。このような液体の紙表面での吸収や浸透, あ るいはぬれについての検討は, 例えば Bristow の動的 吸収性測定装置による方法や，紙の接触角を顕微鏡や モータードライブカメラ，ビデオ撮影などによって連 続的に観察する方法があり，最近数多く発表されてき た。特に Lyne らが Bristow 装置を用いて IJ 記録用紙 の評価 ${ }^{8)}$ 行っている。ここでは IJ 用紙を液体の吸収 挙動によって，すなわちシリカを中心とするへビー コート紙のように表面粗さ指数 $\mathrm{Kr}$ が大きい夕イプと, 表面処理のみのプレーンタイプ紙のように吸収係数 Ka が大きい夕イプにわけている。岡山らは自動液滴 滴下装置を用いて一定量の液滴を紙面上に滴下し，接 触角の経時変化をモータードライブカメラでとらえ ${ }^{9)}$, IJ 記録用のコート紙とプレーン紙とでは接触角の経 時的変化が異なることを示した。

筆者らもBristow 装置を用いて IJ 用紙の水転移量 を調べてその記録特性を検討した ${ }^{10)}$ 。図 5 について補 足説明をする，ここではそれぞれ同一原紙を用いて， 同一㙗料/バインダー比,ほぼ同一塗工量での填料の違 いによる水転移量の比較を行った。SIL は合成シリカ， $\mathrm{SS}$ : 合成珪酸アルミノソーダ, PC : 沈降法軽質炭酸 カルシウム, $\mathrm{NC}$ : 重質炭酸カルシウム, KAO：カオリ ンを示す。バインダーはいずれも PVAである。ここで 明らかなように合成シリカが他の填料と比較して大き
な水転移量を示している。特に 0.01 秒時の値が大きい ことはインクの急速浸透に有効であることが示された。 図 6 は合成シリカを用いてバインダーの種類をそれぞ れ PVA, STA：酸化澱粉, LAT：SBR ラテックスに 変えた場合を示している。ここではバインダーの種類 によってつくられる塗工層の構造及び空隙率の差, 及 び化学的親和性の違いが影響していることがうかがわ れる。図 7 は吸収型の IJ 用紙を用いて溶媒 (水/PEG) 比率を変えた場合の吸収特性である。図中の数字は PEGの比率であり，Ka だけでなく，Krにも影響を与 えている。いずれにしても Bristow 装置による液体転

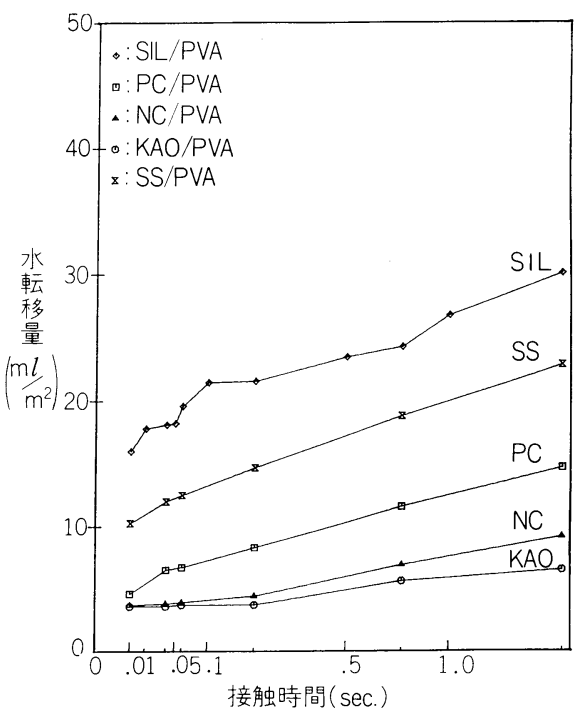

図 5 眞料の違いによる水転移量

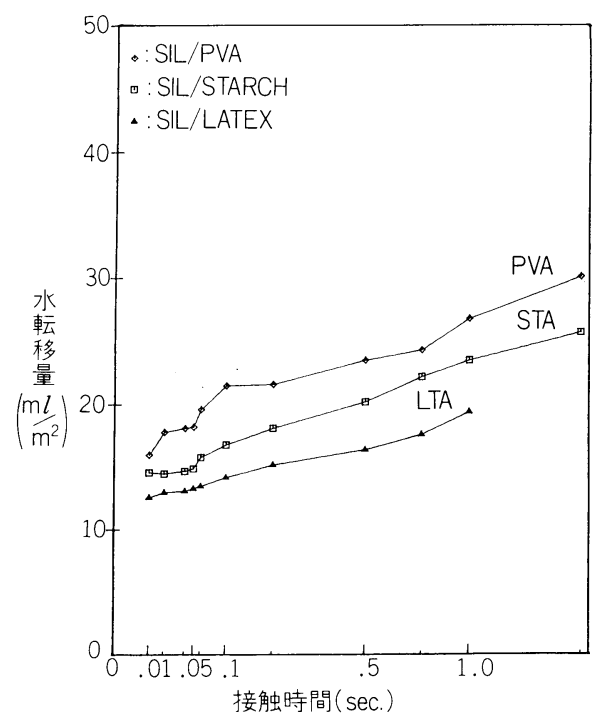

図 6 バインダーの違いによる水転移量 


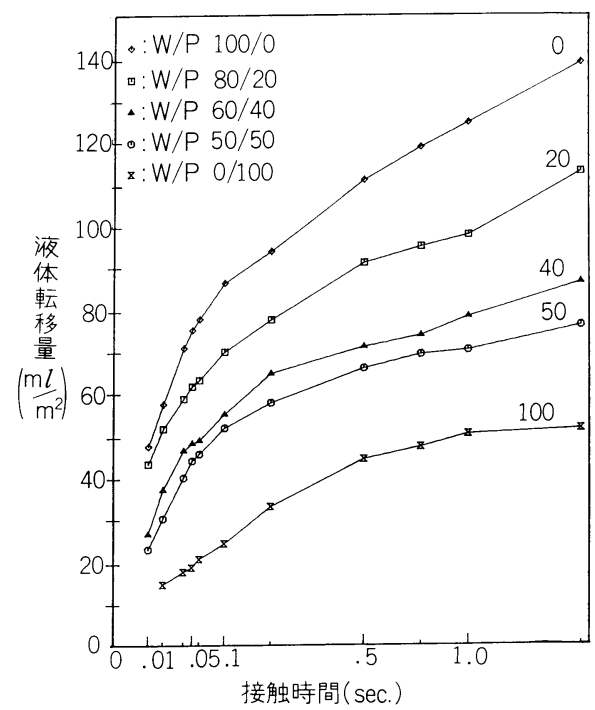

図 7 溶媒比率変化による転移量特性

移量測定により，記録紙のインクに対する吸収特性を ある程度定量的に捉えることができる。

\section{4. ドット径とドットの真円度}

\section{1 ドット径}

IJ 記録にとってドット径及びドットの真円性がコ ントロールされていること，更にこれらがドット間に おいてばらつきが少なく均一であることも重要である。 印字されたドット径の大きさや形は，基本的にはプリ ンタヘッドのノズル径及びインク粒子の飛翔速度に対 して相対的に変化するはずであるが，記録紙の表面構 造及びインクに対する“如”によっても変化する。 またインクの Z方向への吸収速度によって液滴の横 方向への広がりに影響を与え，ドット径が変化する場 合がある。例えば，図8のようにIJ コート紙において はインク吸収層の塗布量を変えることによってドット 径がコントロールされる。図8ではシリカとバイン ダーの比率 $(\mathrm{P} / \mathrm{B}$ 比)を変えたもの 2 種類 $\mathrm{a}(\mathrm{P} / \mathrm{B}-85 /$ $15), \mathrm{b}(\mathrm{P} / \mathrm{B}=60 / 40)$ を同一原紙にいくつか塗布量を 変えて，各ドット径とドット濃度を測定したものであ る。塗布量を数 $\mathrm{g} / \mathrm{m}^{2}$ から $20 \mathrm{~g} / \mathrm{m}^{2}$ 近くまで変えたと ころドット径の変化は $110 \mu$ 程度であった。これらは コート紙に限らず，スーパーカレンダー処理によって インク受容層の空陌量を変えることによって，また非 コート紙でパルプ繊維ベースの記録紙であれば澱粉や $P V A$ などで表面処理を行ってインクに対する浸透性 をコントロールすることなどによって，ドット径をそ れぞれ変化させることが可能である。ドット径が常に

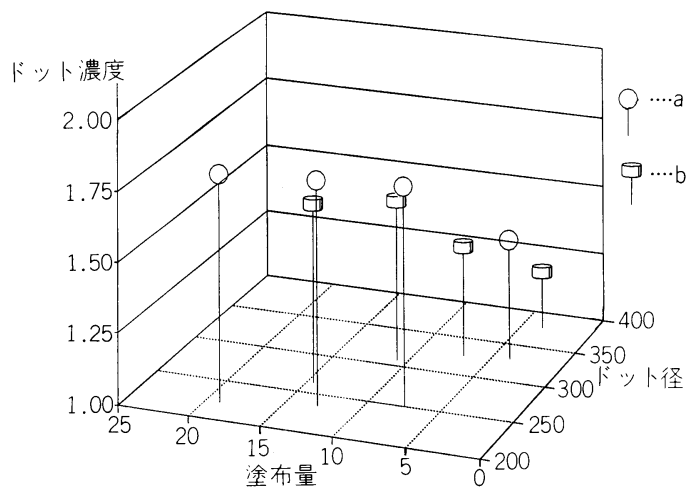

図 8 塗布量とドット径とドット濃度の関係

コントロールされないと，ドットの重なり状態が変わ り, 網点面積率や総合反射濃度が変化して十分な中間 調が再現できなくなる。

\section{2 ドットの真円度}

ドットの真円度とは印字されたドットの形が滑らか で，いかに円に近いかを示すが，このドット真円度は インク粒子の衝突速度や紙の表面構造, 特に物理的な 表面粗さ $(\mathrm{Sr})$ と化学的親和性に依存している。IJ 記 録の場合，中間調を表現する方法としては，面積階調 法と濃度階調法のいずれも使用されるが, 各ドットの 真円度が低下すると画像全体にノイズが入って画質が 低下することがあり, 解像度の高いプリンタなどでは ドットの真円性は重要なファクターである。

ドット真円性の低下の原因には, インク粒子の紙面 への衝突際に起こるインクの跳ね返りによるドットの くずれやサテライト粒子の発生などもあるが, 記録紙 の表面粗さの影響も見られる。触針計による表面粗さ とドットの形状係数 K 1 (真円度)にも相関関係がみら れる ${ }^{10)}$ 。プレーンタイプ (I)，(II）のIJ 用紙は不均 一に存在する空隙やランダムに交差するパルプ繊維に 沿ってインクが流れ易いため真円性は低下する。塗工 紙夕イプ (III)，(IV) は塗布量やバインダー比率にも 依存するが, 一般に微粒の填料, 例えば軽質炭酸カル シウムや不定形の合成シリカを選択することによって 真円性が向上する。しかし塗工紙といっても板状の力 オリンや粒径の大きな填料, さらに疎水性のバイン ダーなどを使用すればインクの均一な浸透が抑えられ， にじみ (Feathring) を生じ真円性が低下するのは当然 のことである。

\section{5。 記 録 濃 度}

記録濃度（反射濃度）は Lambert-Beer の法則から 一般に次式で表わされる。 


$$
\mathrm{D}=\log _{10}\left(\mathrm{I}_{\mathrm{w}} / \mathrm{I}_{\mathrm{B}}\right)
$$

$\mathrm{D}$ : 記録濃度, $\mathrm{I}_{\mathrm{w}}$ : 白紙部の反射光, $\mathrm{I}_{\mathrm{B}}$ : 印字部の反射 光

さらに網点面積比率と単一ドット濃度と総合反射濃 度の関係としては Yule-Nielsenの式があり次式で表 わされる。

$\mathrm{D}=-\mathrm{n} \times \log (1-\mathrm{A}(1-\operatorname{antilog}(-\mathrm{Ds} / \mathrm{n}))$

Ds：単一ドット濃度, $\mathrm{A}$ ：網点面積比率, $\mathrm{n}$ ：ドットゲ イン (係数)

$\mathrm{n}$ はドット濃度,ドット密度，インク吸収層の厚み， インク特性によって変化するものである。IJ 記録は ドット径変調ないしはドット密度変調とドットマト リックスを組み合わせてカラートーンリプロダクショ ンを行っている。いずれにしても特に IJ のフルカラー やマルチカラー記録においては中間調を十分表現する 上で，まず単一ドットの光学濃度が高いことが求めら れる。

典型的な IJ 記録用紙の単一インク粒子の吸収状態 のモデルはさきに図3で表わした。更に図 $9^{11)}$ には吸 収されたインク層の反射の過程を表わした。この定着 した IJ インク層の光学濃度は一般の印刷物に於て論 じられるクベルカ・ムンクの理論で取り扱うことがで きる。例之ば次式はクベルカ・ムンクの式を簡略化し て表面反射率の補正を加えたものである。

$$
(\mathrm{K} / \mathrm{S})_{\lambda}=\frac{\left(1-\mathrm{R}_{\lambda}\right)^{2}}{2(1-\mathrm{r})\left(\mathrm{R}_{\lambda}-\mathrm{r}\right)}
$$

$\mathrm{K}$ : 吸光係数, $\mathrm{S}$ : 散乱係数, $\mathrm{R}_{\lambda}$ : 印字部の反射率,

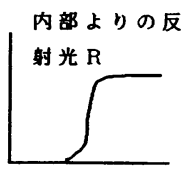

$\lambda$

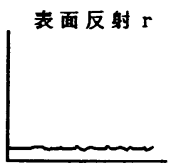

$\lambda$
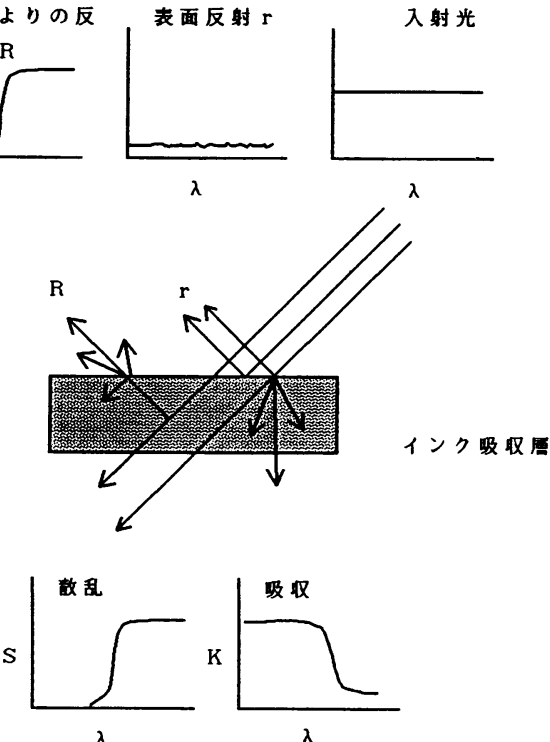

図 9 インク吸収層における反射の過程

\section{$\mathrm{r}$ ：インク吸収層の表面反射率}

また印字部の光学濃度は次式で与えられる。

$$
(\mathrm{K} / \mathrm{S})_{\lambda}=(\mathrm{Kd} / \mathrm{Sd})_{\lambda}+(\mathrm{Ka} / \mathrm{Sa})_{\lambda}
$$

$(\mathrm{Kd} / \mathrm{Sd})_{\lambda}$ : インク染料の光学濃度, $(\mathrm{Ka} / \mathrm{Sa})_{\lambda}$ ：イン ク吸収層の光学濃度

以上のように記録濃度及び色鮮明性，色再現性を向 上するには, インク側からは IJ インクに含有する染料 そのものの吸光係数を高くすることと, K/S の加成性 が成り立つことから染料濃度を高める方法がある。一 方インク吸収層としては，吸光係数が大きく散乱係数 がより小さくなるように材料，その他を選択すること が重要なポイントとなる。

図 10 は吸光係数,散乱係数とドット濃度の関係を示 したものである。ここでは填料として軽カル，酸化千 タン，合成シリカなどを選び，バインダーはPVA と SBR ラテックスを用いて，各塗料を PET フィルムに $2 \mathrm{~g} / \mathrm{m}^{2}$ 塗布したシートを得て, IJ 用黒インクを滴下し て吸光係数と散乱係数, 及びドット濃度を求めたもの である。結果は表 4 にも示したように，シリカのよう に吸光係数が高く散乱係数がより低いものがドット濃 度を高くすることを示した。このように吸光係数は材 料の選択やバインダー比率が影響を与える。また前出 の図 8 の結果では塗布量を増やすことによってドット 濃度がある程度高くなっている。これはインクの浸透 距離をある程度深くする，すなわち $\mathrm{K} / \mathrm{S}$ を大きくして 反射濃度を高める方法である。

水性 IJ 記録の場合, 染料を用いているため発色は減 色混合の原理に基づいている。このため画像の鮮明性 を得るためには印字された（着色された）インク吸収 層の散乱係数が小さい，すなわち透明性が一層高いこ とが望まれる。ある二つの媒質の境界における屈折率 と反射率の関係はフレネルの式で表わされ，さらに吸 光係数 $\mathrm{k}$ を考虑したものは,

表 $4 \mathrm{IJ}$ 塗料の散乱係数, 吸光係数とドット濃度

\begin{tabular}{l|c|c|c|c}
\hline 﨏 料 & $\begin{array}{c}\text { バイン } \\
\text { ダー }\end{array}$ & 散乱係数* & 吸光係数* & $\begin{array}{c}\text { ドット } \\
\text { 濃度 }\end{array}$ \\
\hline シリカ 1 & $\mathrm{a}$ & 426 & 8,516 & 1.70 \\
シリカ 1 & $\mathrm{~b}$ & 397 & 6,568 & 1.53 \\
シリカ 1 & $\mathrm{c}$ & 632 & 6,541 & 1.52 \\
シリカ 1 & $\mathrm{~d}$ & 421 & 8,797 & 1.84 \\
シリカ 2 & $\mathrm{~d}$ & 311 & 5,527 & 1.85 \\
酸化チタン & $\mathrm{d}$ & 983 & 5,090 & 0.96 \\
炭カル & $\mathrm{d}$ & 480 & 4,011 & 1.03 \\
\hline
\end{tabular}

${ }^{*} \mathrm{~cm}^{2} / \mathrm{g}$ 


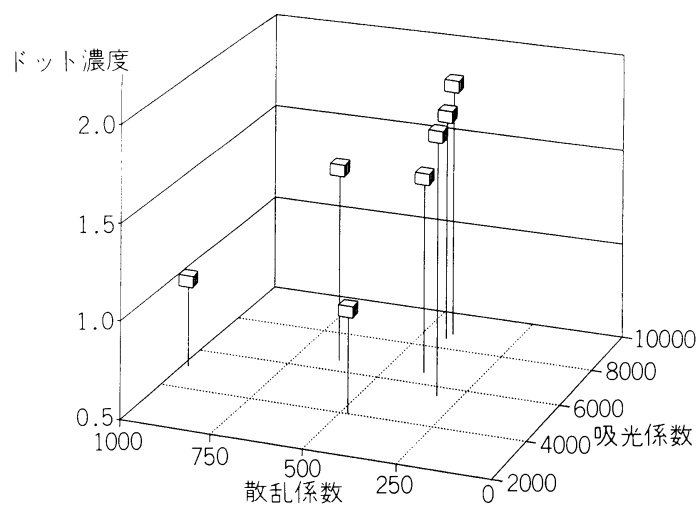

図 10 吸光係数と散乱係数とドット濃度の関係

$$
\rho_{0}=\left\{\left(n_{1}-n_{2}\right)^{2}+k^{2}\right\} /\left\{\left(n_{1}+n_{2}\right)^{2}+k^{2}\right\}
$$

$\rho_{0}$ : 入射角 0 度の反射率, $\mathrm{n}_{1}, \mathrm{n}_{2}$ : 各媒質の屈折率 となる。互いの屈折率が近いものほど反射率が小さい ことを示している。ここで前述の填料について, フレ ネル式から計算した入射角 0 度の反射率と, 測定した 散乱係数の值を比較してみると良い相関関係を示した。 このことからできるだけ反射率を小さくするような材 料を選択すれば散乱係数を小さくすることが可能とな り，IJ 記録紙に適したものが得られることとなる。

\section{6. 記録画像の保存性}

IJ 記録画像に限らず，一般に情報記録画像が受ける 物理的或は化学的作用を記録の保存性の立場からみる と実に様々なものがある。例えば(1)太陽光線, 紫外線, 蛍光灯, 可視線等による耐光性, (2)風雨, 雪, 湿気, オゾン, 酸素等の耐候性, (3)耐水性, (4)加熱, 加圧, 熱処理等による耐熱性あるいは耐昇華性, (5) $\mathrm{NO}_{\mathrm{x}}$, $\mathrm{SO}_{\mathrm{x}}, \mathrm{CO}, \mathrm{H}_{2} \mathrm{~S}$, その他化学薬品等の耐薬品性, (6) 耐 色移行性, (7)耐溶剂性, 耐可塑剤性, 8耐摩耗性など がある。IJ 記録物の場合, 記録紙に定着したインクだ けでなく，インク受容層との相互作用による影響も考 虑しなければならない。

IJ インクの主な着色剂として使用されている酸性 染料ないしは直接染料は, 一般の印刷インクに使用さ れる色素顔料に比較し, 特に耐光性や耐水性が劣るこ とが知られている。また染料だけでなく, 塗工紙にお いては, 填料として使用されるシリカなども, その活 性なシラノール基の影響もあって記録画像の耐光性や 耐候性の低下が促進されるようである。

耐光性や耐候性の改善については, より耐光性に優 れた染料の合成やインクの改良が進められている。ま たインク受容層としてはその中に紫外線吸収剤, 酸化 防止剂，金属酸化物金属塩化物などの添加，さらには
シリカにアルカリ金属化合物を薄くコーティング12) したものを添加する方法などがある。

このほか IJ 記録の保存性の点では, 特に耐室内変色 性 (蛍光灯, 空気), 耐可塑剤性, 耐摩擦性などが問題 とされる。

\section{記録画像の耐水性}

画像耐水性は, 記録画像がある程度水等に濡れても 染料が流れ出さないことを目的としている。一般にア ニオン性の染料（酸性染料，直接染料）に対しインク 受容層にカチオン性のポリマーや化合物を適宜添加す ることによって改善する方法が取られている。インク が記録層に打ち込まれた際, 染料とカチオン物質に よってコンプレックスが形成され水に不溶となる。し かし, これらカチオン性の化合物は染料とイオンコン プレックスをつくることによって, 元来染料が有する 鮮明性や色相を変化させてしまうので注意を要する。 図 11 は純水中に IJ 用酸性染料 (マゼン夕, 濃度 $2.0 \times$ $\left.10^{-8}\right)$ を溶解した可視透過スペクトルに対し, ポリジメ チルジアリル 4 級アンモニウム塩ポリマー $(0.25 \%)$ を加えた際の可視透過スペクトルを示したものである。 図 12 はシリカ塗工紙と上述のポリマーを混ぜたシリ カ塗工紙に，それぞれマゼンダ染料を滴下して反射ス ペクトルを測定したものである。いずれも長波長側に シフトしている。透過スペクトルにより色相色調の変 化が予測できることを示している。図 13 は極性の異な る溶媒にマゼン夕染料を溶解した際の各透過スペクト ルを示す。これらのことから, 染料分子やミセルは溶 媒あるいはポリマーが取り囲む状態によってミセルは 溶媒あるいはポリマーが取り囲む状態によって, 染料 の凝集状態や染料の有する疎水性基や親水性基の配位 のしかたが変化することを示している。また記録紙上

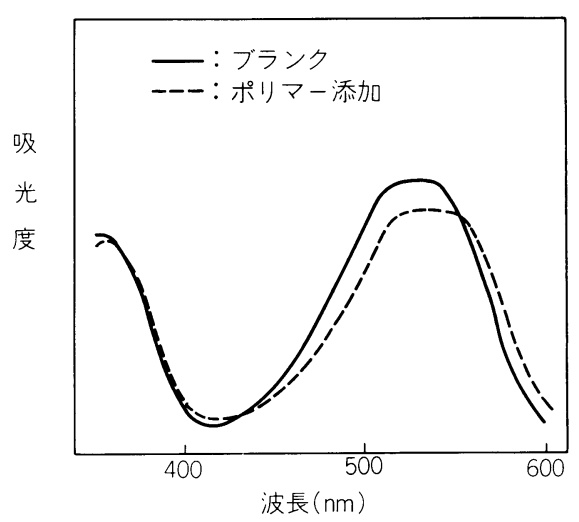

図 11 マゼンダ染料水溶液の可視透過スペクトル ポリマー添加による影響 


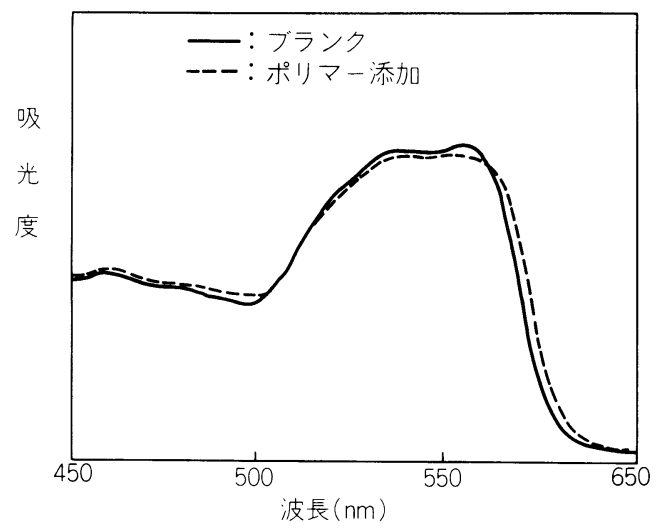

図 12 塗工紙上でのマゼンタ染料の反射スペクトル ポリマー添加による影響

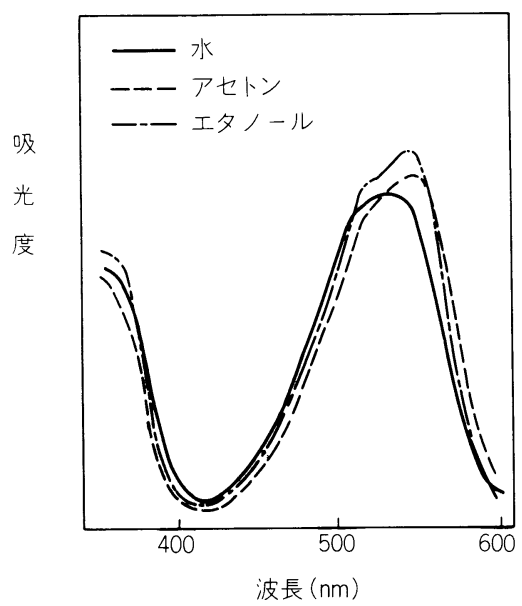

図 13 マゼン夕染料の各種溶媒中の吸収スペクトル

での染料の反射スペクトルの変化は, これら染料固着 剤だけでなく, 塡料, その他の添加剤の影響を受ける ことを考慮する必要がある。

\section{7. 用紙の搬送特性}

情報用紙関連機器においては用紙の給排紙と搬送性 の問題は，一つのシステムを設計していく上で重要な 課題となる。特に IJ 用紙の場合, 汎用の PPC 用紙と 違つて記録特性を重視して改良されているために，紙 の搬送性があまり考慮されないで開発されてきた経緯 がある。一般に紙の搬送性の点で検討すべき項目 ${ }^{13)}$ と しては,

(1)摩擦特性, (2)紙のこし(曲げこわさ)，この二つは 紙の搬送系では特に重要である。次に (3)カール, こ れは雾囲気, 放置の状態等様々な状況を考慮しなけれ
ばならない。(4)表面特性, 紙粉に影響する強度，摩擦 に関連する平滑性や表面性等の点がある。(5)雲囲気特 性, 紙水分を含めて繊維配向性, 寸法安定性を考慮す る必要がある。(6)帯電特性, (7)その他, 記録方法特有 の問題がある。

IJ 記録用紙としては特に(1)〜(5)の項目が重要な課 題であるが, ここでは IJ 記録特有の問題であるコック リング（インク吸収じわ）について述べる。

\section{コックリング}

記録紙が多量のインクを連続的に吸収することに よって記録紙にインク吸収じわが生ずる。パルプ緎維 をべースとするIJ 用紙の場合, この吸収じわによって 記録紙の印字污れ，あるいは給紙トラブルにつながる。 用紙の搬送性に支障をきたす問題であるが，ここでは 液体の紙への浸透膨潤現象として観察してみる。

この現象はコート層, 或はパルブ繊維が大量のイン クを吸収することによってそれぞれが膨潤する。これ によって記録紙の印字部において，部分的な伸びが生 ずるが, 多くの場合, 印字は部分的でありかつ記録用 紙は何等かの形で記録中押さえられているので部分的 に応力が生じ, その結果, 記録紙の印字部分が不均一 にかつ波状にしわが発生したり，時には大きく膨れ上 がりへッドと接触するトラブルとなる。

この現象を捉える方法はいくつかあると思われるが， 今回は音響光学偏向素子を用いて, リアルタイムの画 像が得られる走査型レーザー顕微鏡（1 LM 11，レー ザーテック(株製) によって記録紙表面に水滴を滴下し てモデル的に観察を行った。ここではレーザー顕微鏡 により, 特にインク受容層の繊維や塗工層の膨潤状態 のプロファイルとその滴下前後の変位を読みとること を中心に分析した。当社の代表的な IJ 記録紙 4 種類と PPC 用紙の水滴滴下前のレーザーによる表面粗さプ ロファイルと, それぞれ約 $0.01 \mathrm{~m} l$ の水滴を滴下し 1 分後の状態を比較した。なお浸透しない水に関しては 水取り紙により除いた。図 $14 \mathbf{a} 〜 \mathbf{c}$ はそのプロファイ ルの例である。インク吸収型のプレーンタイプ紙 ( I ) は水を吸収することにより大きくプロファイルが変化 するが, PPC 用紙や非吸収型のプレーンタイプ紙 (II) ではほとんど変化はない。シリカのコート紙（III）で は凹凸がやや激しくなりプロファイルに変化がみられ る程度である。同時に吸水前後の変位を測定したとこ ろ表 5 のようになった。（ I ）の膨潤率は $27.7 \%$ とかな ク大きな值を示し, 紙厚の変化やコックリングへの影 響がうかがわれる。一方（III）でも変位は大きいが, プロファイルからみるようにある程度均一に膨れるよ うである。しかしマクロ的にはコックリングの要因に 
a)プレーンタイプ( I )
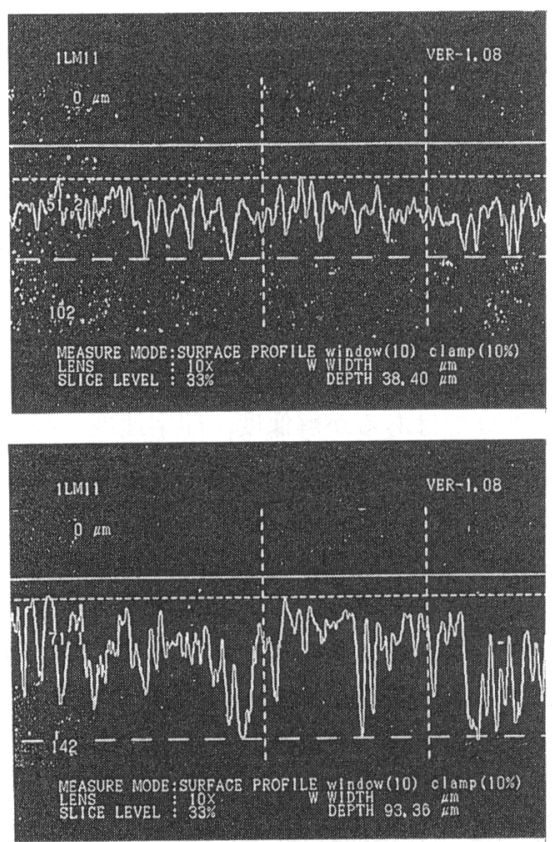

c)塗工紙 (III)の 1
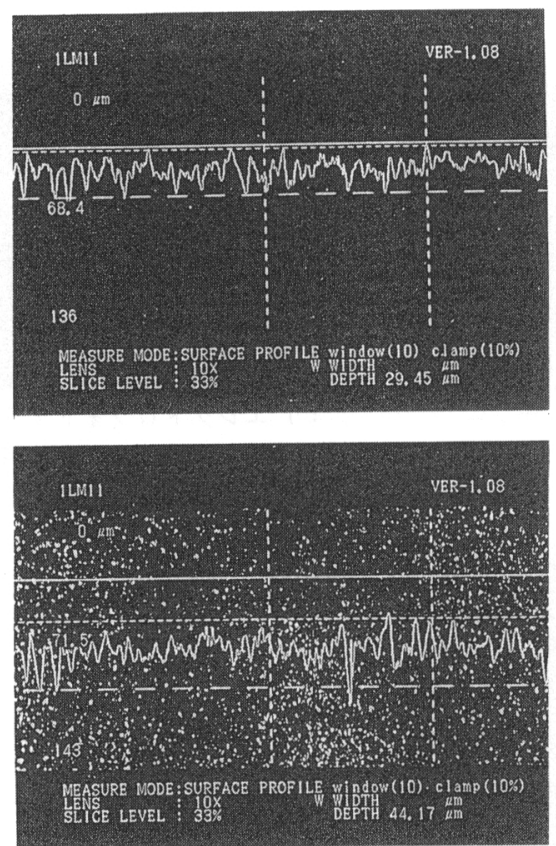

b)プレーンタイプ( II )
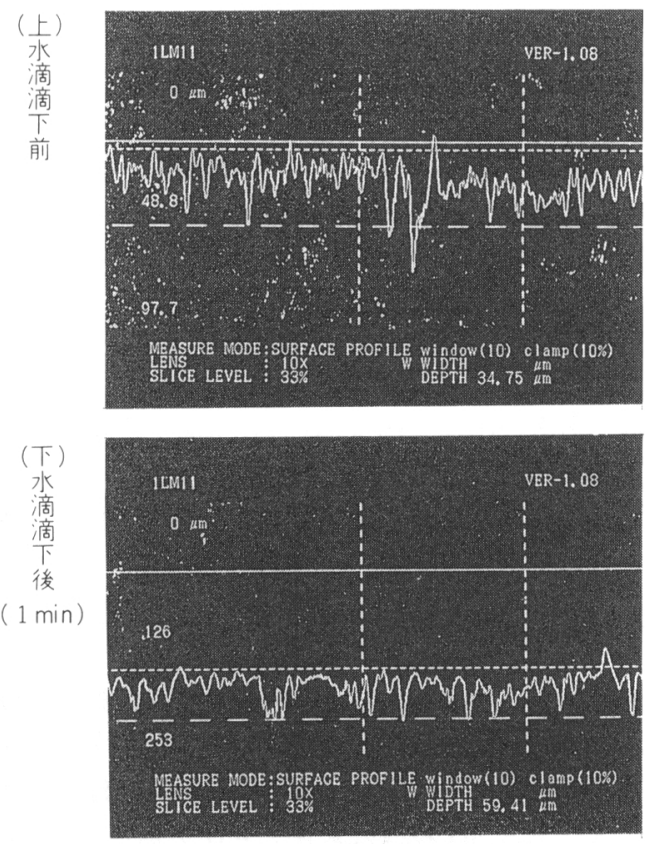

d)塗工紙タイプ(III)の2
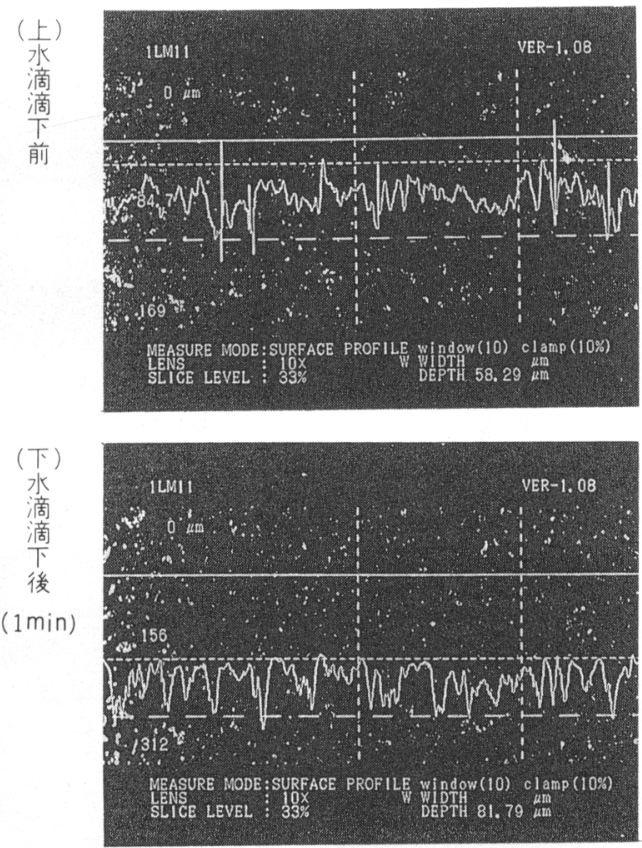

図 14 レーザー顕微鏡による IJ 紙表面プロファイル 
表 5 IJ 用紙の膨潤変化

\begin{tabular}{l|c|r|r}
\hline \multicolumn{1}{|c|}{ タイプ } & $\begin{array}{c}\text { 厚さ } \\
\mu \mathrm{m}\end{array}$ & $\begin{array}{c}\text { 膨潤厚さ } \\
\mu \mathrm{m}^{1)}\end{array}$ & $\begin{array}{c}\text { 膨潤率 } \\
\%\end{array}$ \\
\hline ( I ) & 92.8 & 25.7 & 27.7 \\
( II ) & 78.8 & 4.8 & 6.1 \\
( III ) の 1 & 97.3 & 16.2 & 16.6 \\
( III ) の2 & 97.3 & 21.9 & 22.5 \\
PPC 用紙 & 88.0 & 6.7 & 7.6 \\
\hline
\end{tabular}

注 ${ }^{1)}$ 膨潤厚さは水滴滴下前と滴下後 1 分 後の読取り值の差

なり得る現象である。

IJ カラー記録ではインク粒子を重ねて打ち込むた め, どうしてもインク量が多くなりコックリング現象 が生じる。これは IJ 記録紙の一つの課題である。

\section{IJ 技術の最近の動き}

カラー記録技術を，カラー複写機を中心とする分野 とカラーハードコピー機の分野とに分けてみる。前者 には電子写真, 銀塩写真, サイカラー, IJ, 熱転写記録 などの記録方式がある。IJ 技術はエレクトロフォトグ ラフィー (電子写真) などではカバーしにくい手軽な 複写機, あるいはまたA1 以上の大型の複写機にと幅
広く応用可能である。後者の分野では IJ, 熱転写記 録, 静電記録, 銀塩写真などが中心であるが, この中 でIJ はカラーとして鮮明な色彩, 解像度, 印字速度, コストなど様々な点で優位性をうかがわれ発展が期待 されている。IJ 技術は繰り返すようであるが，容易に カラ一記録が得られることにある。ここ数年でいくつ かの低価格のマルチカラープリンタが販売されてきた が，これらも最近は解像度が $180 \mathrm{dpi}$ 以上となり，画質 が一段と向上してきている。昨秋は $400 \mathrm{dpi} て ゙ \mathrm{~A} 1$ 用紙 が印字可能な大型のバブルジェット方式によるフルカ ラーコピー機の発売が発表された。更に今年に入って モノクロではあるが解像度, 印字速度, 静肃性などの 点でレーザー或はドットのページプリンタの性能を上 回るIJ プリンタ 2 機種(キャノン, セイコーエプソン) の発売が発表された。例えば IJ 記録を含むいくつかの ノンインパクト記録による文字の印字状態を拡大写真 で比較してみると次のようになる(図 15)。モノクロの 分野でも現在展開されている技術を凌駕するIJ 技術 が現れたことは，今後カラー記録の分野でも大いに期 待できるものと考える。なお終りに掲載した IJ カラー 記録画像写真は，カラーインクジェットプリンター IRIS 3024 (荷電制御型, 解像度 $300 \mathrm{dpi}$ ) により当社の 塗工紙 FC-3 に出力したものである。印字サンプルは

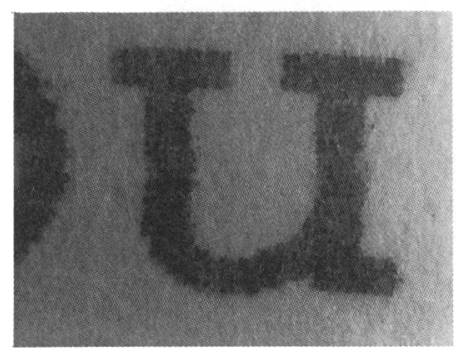

a) インクジェット バブルジェット (360 DPI)

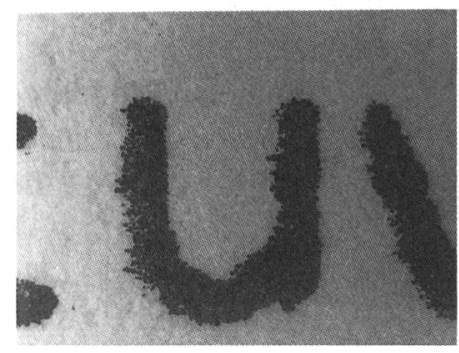

d）エレクトログラフィー イオンディポジション

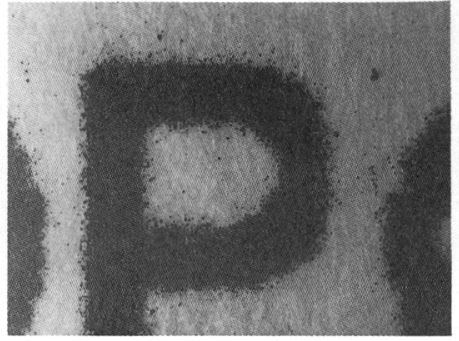

b ） マグネットグラフィー

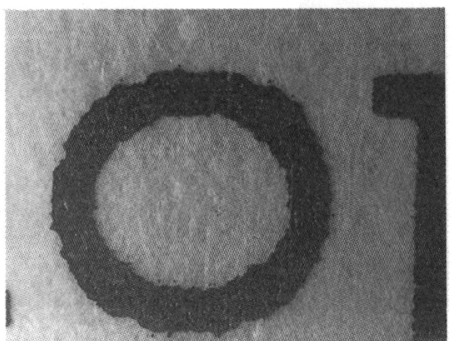

e ）通電熱転写

(240 pel/inch)

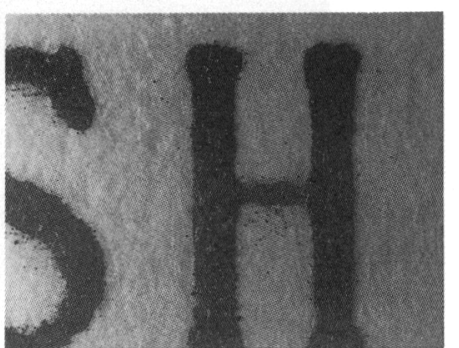

c ）エレクトロフォトグラフィー レーザープリン夕 (240 DPI)

(写真で約 30 倍)

図 15 各種ノンインパクトプリンタによる印字状態 
丸紅エレクトロニクス株からのご協力によるものであ る。

\section{9. まと め}

以上 IJ 記録用紙の要求物性についていくつかの点 から述べてきたが, 簡易であることを特徴とする IJ 技 術であるが, 用紙の側からみると結構複雑な要素が盛 り込まれていることがわかる。またここで述べるまで もなく, IJ 用紙についてはすでに様々な分野の方から 数多くの報告がなされておりそれらを参考にされたい。 最近の技術動向でもみたように，ここ数年 IJ 機器, インク, 用紙とも飛躍的に改善されてきており, また 情報処理技術の飛躍的な発展とともに, カラ一記録技 術全体への再認識も進み，IJ 技術は最初にも述べたよ うな課題が克服されればその優位性がいかんなく発揮 され大きく普及するものと思われる。

\section{参考文献}

1) W. K. SOBOTKA, Tappi Proceeding I. P. G. A. Conf., 14 (1988)

2)「米カラー複写機市場」電波新聞，4/8，12，13, 1989

3）プロダクトファイル，日経バイト61(7) : 239 (1989)
4) LYNE, M. B., J. IMAGING TEC. 12(2) : 80 (1986)

5）太田徳也，信頼性を左右するインクジェットイン クの設計，日経エレクトロニクス 303 11-8, 148 (1982)

6）太田徳也，インクジェット記録用紙とインク，第 18 回パルプシンポジウム (纎維学会紙パルプ研究 委員会), 36 (1983)

7）大渡章夫, 田中敬子, 林 広子, 竹本清彦, 松崎 真, 上條雅則, 第 4 回 NIP シンポジウム論文集(電 子写真学会), 93 (1988)

8) LYNE, M. B. AND ASPLER, J. S., Tappi J. 68(5) : 106 (1985)

9）岡山隆之, 木村重昭, 大江礼三郎：紙バ技協誌, $39(12), 1157$ (1985)

10）小島 裕, 大森隆志, 永井弘一：第 2 回 NIP シン ポジウム論文集 (電子写真学会), 73 (1985)

11）納谷嘉信：産業色彩学, 176-182, 朝倉書店, (1980)

12）高橋正男, 佐藤悌治, 小川政英：紙パ技協誌, 42(10)，923 (1988)

13）門屋 卓：情報記録用紙と紙の物性, 印刷・情報 記録研究会講座講演要旨集 (高分子学会), 15 (1987) 


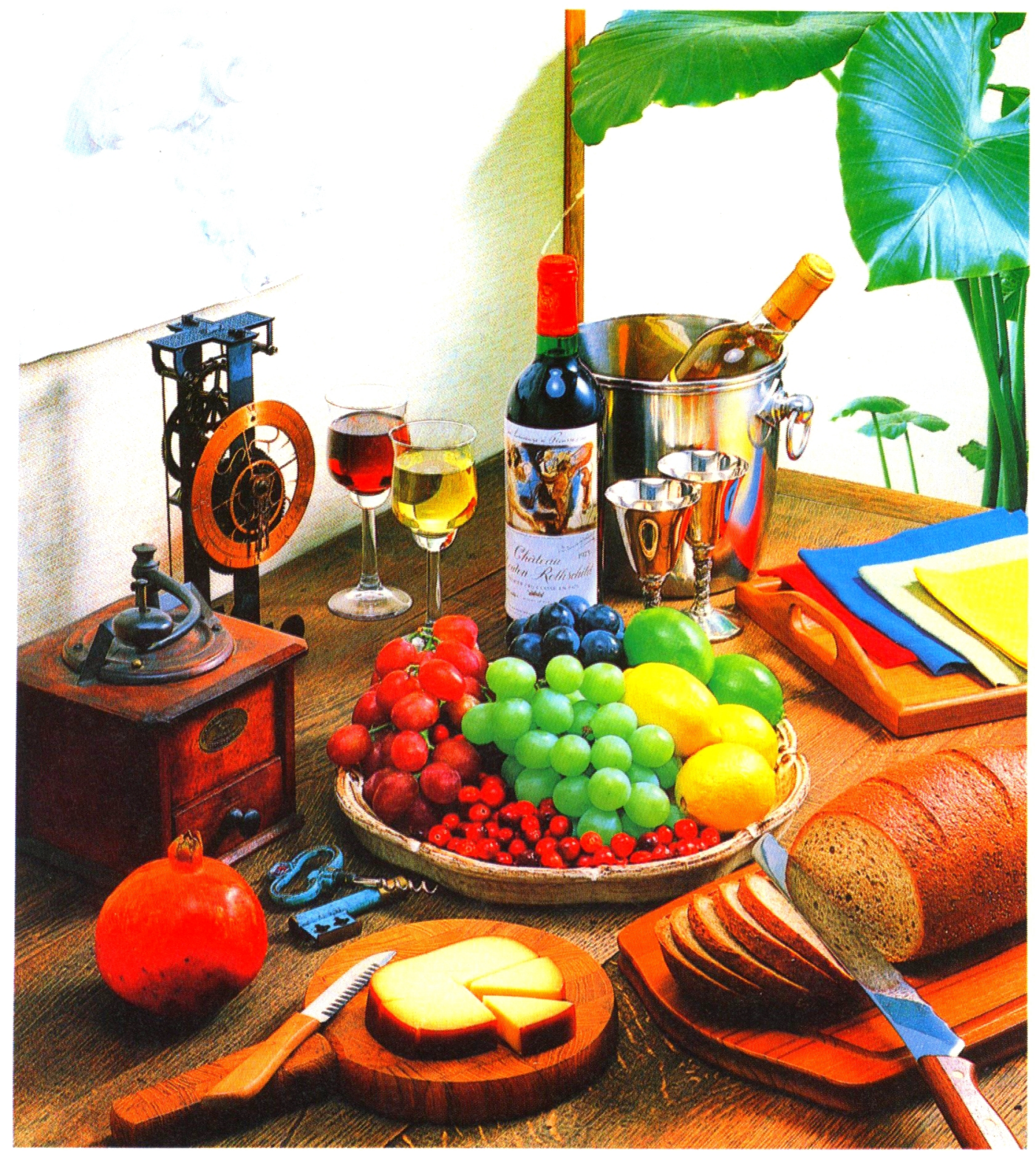

カラーインクジェットプリンターIRIS 3024 (荷電制御型，解像度 $300 \mathrm{dpi}$ ）によるIJ塗工䖰出力例 